\title{
IMPLEMENTASI ALGORITMA NAIVE BAYES UNTUK MENGETAHUI MINAT BELI KONSUMEN TERHADAP SARANG BURUNG WALET
}

\section{IMPLEMENTATION OF NAIVE BAYES ALGORITHM TO KNOW CONSUMER'S BUYING INTEREST IN SWALLOW'S NEST}

\author{
Sofyan', Siti Nur Asia², Mardewi ${ }^{3}$

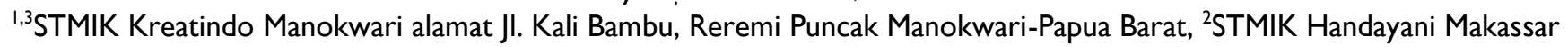 \\ Alamat JI Adikasa Baru Makassar, \\ sofyanarifin018@gmail.com',nurasia93@gmail.com², mardewi0004@gmail.com³
}

\begin{abstract}
ABSTRAK
Implementasi Algoritma Naive Bayes Untuk Mengetahui minat beli konsumen terhadap sarang burung walet. Penelitian ini mengimplementasikan algoritms naive bayes untuk pengelolaan analisis data yang digunakan untuk mengklasifikasi data kasus baru berdasarkan sampel dari data training dengan menghitung nilai peluang atau probabilitas dari setiap kelas. Jumlah sampel yang digunakan dalam analisis ini terdapat 25 record data training yang dihitung secara manual maupun menggunakan aplikasi rapidminer. Hasil perhitungan dengan menerapkan algoritma naïve bayes dengan melakukan perkalian nilai probabilitas atau nilai peluang dari kasus yang diambil dari data training dapat dilihat bahwa $P(X \mid$ Klasifikasi="Minat") mendapatkan hasil yang lebih besar dari $P(X \mid$ Klasifiakasi='Tidak") dengan nilai dari minat $=0.233739$ dan nilai 0.00078 . Selain itu hasil pengolahan data dengan aplikasi rapidminer bahwa data kasus baru yang ada pada data training termasuk dalam kategori klasifikasi "Minat" dengan hasil prediksi minat dengan angka confidentce minat sebesar 0.983 dengan konsumen 24 dan 0.990 untuk konsumen 25 dengan perbandingan hasil confidence tidak sebesar 0,017 dan 0.010. Sehingga dapat diambil kesimpulan bahwa dua data kasus baru yang ada pada data training masuk dalam kategori klasifikasi "Minat" $\mathrm{Hal}$ ini menunjukkan bahwa hasil pengolahan dengan algoritma naive bayes sangat akurat.
\end{abstract} Kata kunci: Minat, Navie Bayes, Sarang, Burung Walet.

\begin{abstract}
Implementation of the Naive Bayes Algorithm to determine consumer buying interest in swallow nests. This study implements the Naive Bayes algorithm for managing data analysis which is used to classify new case data based on samples from training data by calculating the probability or probability value of each class. The number of samples used in this analysis is 25 training data records that are calculated manually or using the rapidminer application. The results of the calculation by applying the nave Bayes algorithm by multiplying the probability value or the probability value of the cases taken from the training data can be seen that $P(X \mid$ Classification="'Interest") gets greater results than $P(X \mid$ Classification='No" $)$ with a value of interest $=0.233739$ and $a$ value of 0.00078. In addition, the results of data processing with the rapidminer application show that the new case data in the training data is included in the "Interest" classification category with the prediction results of interest with an interest confidence number of 0.983 with 24 consumers and 0.990 for 25 consumers with a comparison of confidence results not 0.017 and 0.010 . So it can be concluded that the two new case data in the training data are included in the "Interest" classification category. This shows that the results of processing with the Naive Bayes algorithm are very accurate.
\end{abstract} Keywords: Interest, Navie Bayes, Nest, Swallow.

Pendahuluan

Komunitas usaha sarang burung wallet di Indonesia mulai menyebar di berbagai wilayah. Berkembangnya sarang burung walet ini dapat dilihat dari lokasi baru yang terus bermunculan. Peluang bisnis sarang burung walet yang cenderung meningkat ini merupakan dari jumlah ekspor sarang burung walet yang terlihat. Tingginya pengiriman sarang burung walet menandakan permintaan 
akan sarang burung walet yang semakin pesat dan berkembang. Sarang burung walet merupakan komoditi ekspor yang bernilai tinggi.

Burung Walet (Collocalia fuciphaga) merupakan ternak unggas yang dibudidayakan dengan sarang sebagai produksi utama. Sarang burung walet merupakan hasil dari air liur burung walet yang saat ini memiliki nilai ekonomis yang tinggi oleh karenanya dibudidayakan. Produksi sarang burung walet dipengaruhi oleh berbagai faktor, salah satunya adalah faktor kondisi lingkungannya. Lingkungan burung walet terdiri dari habitat mikro dan habitat makro.

Salah satu usaha sarang walet yang cukup berkembang di papua adalah usaha sarang walet super kristal rumahan di kabupaten manokwari papua barat Usaha sarang burung walet ini merupakan usaha yang sangat menjanjikan dikarenakan harga jual untuk perkilonya yang tinggi. Harga sarang walet di pasaran sangat tinggi untuk memenuhi permintaan pasar sehingga para pengusaha sarang burung walet mulai mengembangkan usaha rumah sarang burung walet.

Persaingan dalam bisnis membuat para pelakunya harus selalu memikirkan strategi-strategi terobosan yang dapat menjamin kelangsungan bisnis mereka. Pada suatu perusahaan memiliki ketersediaan data yang melimpah. Ini melahirkan kebutuhan akan adanya teknologi yang dapat memanfaatkannya untuk membangkitkan pengetahuan-pengetahuan baru, yang dapat membantu dalam pengaturan strategi dalam menjalankan bisnis. Prediksi minat konsumen akan sangat penting bagi pengusaha dalam bisnisnya, dimana dengan adanya prediksi minat konsumen terhadap sarang walet dapat mengambil suatu keputusan atau strategi yang benar dan tepat bagi konsumennya.

Metode Klasifikasi adalah proses untuk menemukan model atau fungsi yang menjelaskan atau membedakan konsep atau kelas data, dengan tujuan untuk dapat memperkirakan kelas dari suatu objek yang labelnya tidak diketahui. Dalam mencapai tujuan tersebut, proses klasifikasi membentuk suatu model yang mampu membedakan data kedalam kelas-kelas yang berbeda berdasarkan aturan atau fungsi tertentu. Model itu sendiri bisa berupa aturan "jika-maka", berupa pohon keputusan, atau formula matematis.

Algoritma Naive Bayes merupakan salah satu algoritma yang terdapat pada teknik klasifikasi. Naive Bayes merupakan pengklasifikasian dengan metode probabilitas dan statistik yang dikemukan oleh ilmuwan Inggris Thomas Bayes, yaitu memprediksi peluang di masa depan berdasarkan pengalaman dimasa sebelumnya sehingga dikenal sebagai Teorema Bayes. Teorema tersebut dikombinasikan dengan Naive dimana diasumsikan kondisi antar atribut saling bebas.

Metode Naive Bayes dapat digunakan untuk membuat aplikasi klasifikasi dalam beberapa kasus. Oleh sebab itu dalam penelitian ini metode naive bayes digunakan untuk memberikan gambaran mengenai minat beli pelanggan terhadap sarang walet. Penelitian ini menggunakan sampel yang diambil berdasarkan data yang ada yang digunakan sebagai data pelatihan untuk menetapkan kriteria dalam menentukan minat pelanggan terhdap sarang walet.

Berdasarkan latar belakang tersebut maka diperlukan sebuah sistem untuk klasifikasi untuk mengetahui minat pelanggan terhadap sarang walet Maka dari itu, penulis berinisiatif untuk merancang dan menerapkan sebuah sistem yaitu Implementasi Algoritma Naïve Bayes Untuk Mengetahui Minat Beli Konsumen Terhadap Sarang Burung Walet.

\section{Metode}

A. Minat Beli

Minat beli (willingness to buy) merupakan bagian dari komponen perilaku dalam sikap mengkonsumsi. Minat beli konsumen adalah tahap dimana konsumen membentuk pilihan mereka diantara beberapa merek yang tergabung dalam perangkat pilihan, kemudian pada akhirnya melakukan suatu pembelian pada suatu altenatif yang paling disukainya atau proses yang dilalui konsumen untuk membeli suatu barang atau jasa yang didasari oleh bermacam pertimbangan. Minat beli merupakan sesuatu yang berhubungan dengan rencana konsumen untuk membeli produk tertentu serta berapa banyak unit produk yang dibutuhkan pada periode tertentu". Berdasarkan uraian di atas dapat disimpulkan minat beli merupakan pernyataan mental dari konsumen yang merefleksikan rencana pembelian sejumlah produk dengan merek tertentu.

\section{B. Klasifikasi Naive Bayes}

Algoritma Naïve Bayes Classification merupakan algoritma yang digunakan untuk mencari nilai probabilitas tertinggi untuk mengklasifikasi data uji pada kategori yang paling tepat. Proses klasifikasi metode NBC dibagi menjadi dua tahap, yaitu tahap pelatihan dan tahap klasifikasi. Tahap pelatihan dilakukan proses analisis data untuk menghitung jumlah kemunculan kata terhadap sampel data yang sudah diketahui kategorinya. Data-data ini digunakan untuk bahan pembelajaran pada tahap proses klasifikasi untuk menentukan data uji termasuk dalam kategori mana. Teorema Bayes memiliki bentuk umum yang ditunjukkan pada persamaan.

$$
P(H \mid X)=\frac{P(X \mid H) P(H)}{P(X)}
$$


Pada saat klasifikasi algoritma akan mencari probabilitas tertinggi dari semua kategori dokumen yang diujikan (Vmap). Dengan menerapkan teorema Bayes ditunjukan pada persamaan (I) dapat ditulis :

$V$ map $=\operatorname{argmax}_{V j \in V} \frac{P(X 1, X 2, X 3, \ldots X n \mid V j)}{P(X 1, X 2, X 3, \ldots X n)}$

Untuk $P(x 1, x 2, x 3)$ nilainya konstan untuk semua kategori $(\mathrm{Vj})$ sehingga persamaan (2) menjadi:

Vmap $=\operatorname{argmax} V j \in V \quad(X I, \quad X 2, \quad X 3, \ldots$ $X n \mid V j)$

Persamaan diatas dapat disederhanakan yang ditunjukkan pada persamaan (3).

Vmap $=\operatorname{argmax} V j \in V \quad n \quad=i \quad$ । $(W k \mid V j)(V j) \ldots \ldots \ldots \ldots \ldots \ldots \ldots \ldots \ldots . . . . . . . . .(4)$

Dimana $V j$ adalah kategori j, sedangkan $P(V j)$ adalah probabilitas $\mathrm{Vj}$, dan $\mathrm{P}(\mathrm{Wk} \mid \mathrm{Vj})$ adalah probabilitas $\mathrm{Wk}$ dalam kategori Vj.Untuk menghitung $P(V j)$ dan $P(W k \mid V j)$ dihitung pada saat pelatihan dimana ditunjukkan pada persamaan (5) dan (6).

$P(V j)=\frac{\mid \text { doc } j \mid}{\mid \text { contoh } \mid}$

Dimana |doc j | adalah jumlah dokumen dari setiap kategori, sedangkan |contoh | adalah jumlah dokumen dari semua kategori.

$P(W k \mid V j)=\frac{n k+1}{n+\mid \text { kosakata } \mid}$

Dimana nk adalah jumlah frekuensi dari setiap kata Wk dalam dokumen yang berkategori $\mathrm{Vj}$, sedangkan nilai $\mathrm{n}$ adalah jumlah kata dari dokumen berkategoriVj, dan |kosakata| adalah jumlah semua kata dari semua kategori.(Trisetiyo and Wibowo 2019)

\section{Pengenalan Pola, Data Mining dan Machine Learning \\ Menurut Santoso Pengenalan pola adalah suatu} disiplin ilmu yang mempelajari cara-cara mengklasifikasikan obyek ke beberapa kelas atau kategori dan mengenali kecenderungan data. Tergantung pada aplikasinya, obyek-obyek ini bisa berupa pasien, mahasiswa, pemohon kredit, image atau signal atau pengukuran lain yang perlu diklasifikasikan atau dicari fungsi regresinya ( 2007:23). Data mining, sering juga disebut knowledge discovery in database (KDD), adalah kegiatan yang meliputi pengumpulan, pemakaian data historis untuk menemukan keteraturan, pola atau hubungan dalam set data berukuran besar. Keluaran dari data mining ini bisa dipakai untuk memperbaiki pengambilan keputusan di masa depan. Sehingga istilah pattern recognition jarang digunakan karena termasuk bagian dari datamining .Machine Learning adalah suatu area dalam artificial intelligence atau kecerdasan buatan yang berhubungan dengan pengembangan teknik-teknik yang bisa diprogramkan dan belajar dari data masa lalu. Pengenalan pola, data mining dan machine learning sering dipakai untuk menyebut sesuatu yang sama. Bidang ini bersinggungan dengan ilmu probabilitas dan statistic kadang juga optimasi.Machine learning menjadi alat analisis dalam data mining.Bagaimna bidang-bidang ini berhubungan bisa dilihat dalam gambar 2.1 Santoso (2007:23).

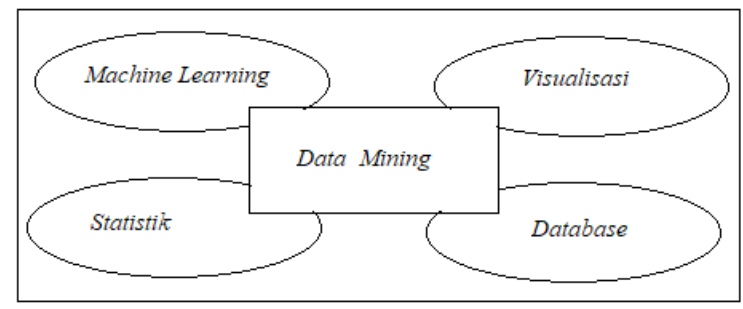

Gambar I Hubungan Ilmu Data Maning,Machine Learning dan Pengelan Pola

D. Klasifikasi

Klasifikasi adalah suatu fungsionalitas data mining yang akan menghasilkan model untuk memprediksi kelas atau kategori atau kategori dari objek-objek di dalam basis data. Klasifikasi merupakan proses yang terdiri dari dua tahap, yaitu tahap pembelanjaran dan tahap pengklasifikasian. Pada tahap pembelajaran, sebuah algoritma klasifikasi akan membangun sebuah model klasifikasi dengan cara menganalisis training data. Tahap pembelajaran dapat juga dipandang sebagai tahap pembentukan fungsi atau pemetaan $Y=F(X)$ dimana $Y$ adalah kelas hasil prediksi dan $X$ adalah tuple yang ingin diprediksi kelasnya. Selanjutnya pada tahap pengklasifikasian, model yang telah dihasilkan akan digunakan untuk melakukan klasifikasi. Tahapan dari klasifikasi dalam data mining terdiri dari:

1. pembangunan model, dalam tahapan ini dibuat sebuah model untuk menyelesaikan masalah klasifikasi class atau attribut dalam data,.

2. Penerapan model, pada tahapan ini model yang sudah dibangun sebelumnya digunakan untuk menentukan attribute atau class dari sebuah data baru yang attribut atau classnya belum diketahui sebelumnya

3. Evaluasi, pada tahapan ini hasil dari penerapan model pada tahapan sebelumnya dievaluasi menggunakan parameter terukur untuk menentukan apakah model tersebut dapat diterima.

E. Konsep Dasar Sistem Pendukung Keputusan

Wikipedia.(2015). Sistem pendukung keputusan adalah bagian dari sistem informasi berbasis computer (termasuk sistem berbasis pengetahuan (manajemen 
pengetahuan)) yang di pakai untuk mendukung pengambilan keputusan dalam sebuah organisasi atau perusahaan.

Sistem pendukung keputusan (Decision Support System) adalah bagian dari sistem informasi berbasis computer, termasuk sistem berbasis pengetahuan (manajemen pengetahuan) yang di pakai untuk mendukung pengambilan keputusan dalam suatu organisasi atau perusahaan.

Dalam proses pengambilan keputusan terdapat model proses pengambilan keputusan yang terdiri dari 4 fase, yaitu

I. Inteligensi (intelegence)

Fase ini merupakan aktifitas yang menekankan identifikasi situasi atau peluang - peluang masalah.

2. Desain (design)

Fase ini merupakan penemuan atau pengembangan dan menganalisis tindakan yang mungkin akan dilakukan. Hal ini meliputi pemahaman terhadap masalah dan menguji solusi yang layak

3. Pilihan (choise)

Fase ini merupakan tindakan pengambilan keputusan yang kritis, dimana dibuat suatu keputusan yang nyata dan di ambil suatu komitmen untuk mengikuti suatu tindakan tertentu.

4. Implementasi (implementation)

F. Komponen Sistem Pendukung

Efraim Turban, dkk (2005 : 143) menyimpulkan "sistem pendukung keputusan terdiri dari 4 komponen utama atau subsistem" yaitu :

I. Subsistem manajemen data

Subsistem mencakup satu basis data (database) yang berisi data yang relevan dan dikelola oleh perangkat lunak yang disebut Database Management System (DBMS).

2. Subsistem manajemen model

Subsistem manajemen model merupakan perangkat lunak yang berkaitan dengan bidan -bidang seperti keuangan, statistic, manajemen, atau model-model kuantitatif yang memiliki kemampuan untuk melakukan analisa sistem.Perangkat lunak ini dikenal dengan Model Base Mangement System (MBMS).Subsistem ini memiliki komponen yang dapat dikoneksikan ke penyimpanan eksternal yang ada pada model.

3. Susbsitem antarmuka pengguna

Digunakan sebagai media interaksi antara sistem dengan pengguna.Pengguna dapat berkomunikasi dengan Sistem Pendukung Keputusan dan memerintahkan Sistem Pendukung Keputusan melalui subsitem ini.

4. Subsistem manajemen berbasis pengetahuan.

Subsistem ini dapat mendukung subsistem lain atau bertindak sebagai komponen yang berdiri sendiri dan tidak terkait dengan komponen lain.

\section{Hasil Dan Pembahasan}

Pada penelitian ini menggunakan algoritma naive bayes untuk mengetahui minat konsumen terhadap sarang walet adalah. Tahapan pertama yang dilakukan dalam penelitian ini dengan mengumpulkan data penjualan yang telah di dijual sebelumnya, Kemudian menentukan kriteria yang digunakan untuk parameter penentuan penilaian. Dengan mengimplementasikan algoritma naïve bayes dalam penentuan minat beli sarang wallet maka dapat mengatasi permasalahan yang terjadi sehingga pemilik usaha dapat melakukan strtegi pemasaran dengan baik. Berdasarkan penjelasan yang telah diuraikan maka dalam mengatasi permasalahan untuk menentukan minat beli sarang walet diperlukan suatu analisis bagi pemiliki usaha sarang walet yang di uraikan sebagai berikut:

\section{A. Menentukan Kriteria}

pada tabel I merupakan tabel penentuan kreateria sarang burung walet dimana terdapat kualitas, masa penyimpanan, ketersedian dan harga.

Tabel I Penentian Kriteria

\begin{tabular}{llll}
\hline Kualitas & $\begin{array}{l}\text { Masa } \\
\text { Penyimpanan }\end{array}$ & $\begin{array}{l}\text { ketersediaa } \\
\mathrm{n}\end{array}$ & Harga \\
\hline Sedang & 7 bulan & Sedikit & Rendah \\
Baik & 9 bulan & Banyak & Sedang \\
$\begin{array}{l}\text { Sangat } \\
\text { Baik }\end{array}$ & 12 bulan & Sedang & Tinggi \\
\hline
\end{tabular}

B. Analisis Perhitungan dengan Algoritma Naive Bayes

Pada tabel 2 dibawah ini merupakan tabel data training yang ambil dari laporan data penjualan sarang walet pada kabupaten manokwari. Sampel data yang digunakan dalam studi kasus ini merupakan sebagian data dari data penjulan, jumlah sampel yang digunakan sebanyak 25 sampel yang dijelaskan pada tabel berikut ini.

Tabel 2 Data Training

\begin{tabular}{|c|c|c|c|c|c|c|}
\hline $\begin{array}{l}\text { Konsu } \\
\text { men }\end{array}$ & $\begin{array}{l}\text { Sarang } \\
\text { Walet }\end{array}$ & $\begin{array}{l}\text { Kuali } \\
\text { tas }\end{array}$ & $\begin{array}{l}\text { Masa } \\
\text { penyi } \\
\text { mpan } \\
\text { an }\end{array}$ & $\begin{array}{l}\text { Keters } \\
\text { ediaan }\end{array}$ & $\begin{array}{l}\text { Harg } \\
\text { a }\end{array}$ & $\begin{array}{l}\text { Ko } \\
\text { nsu } \\
\text { me } \\
\text { n }\end{array}$ \\
\hline$x I$ & SWOI & $\begin{array}{l}\text { sanga } \\
t \text { baik }\end{array}$ & $\begin{array}{l}12 \\
\text { bulan }\end{array}$ & banyak & tinggi & XI \\
\hline$\times 2$ & SWOI & $\begin{array}{l}\text { sanga } \\
\text { t baik }\end{array}$ & $\begin{array}{l}12 \\
\text { bulan }\end{array}$ & banyak & tinggi & $\times 2$ \\
\hline
\end{tabular}




\begin{tabular}{|c|c|c|c|c|c|c|}
\hline$x 3$ & SW04 & $\begin{array}{l}\text { Seda } \\
\text { ng } \\
\text { Seda }\end{array}$ & $\begin{array}{l}7 \\
\text { bulan } \\
9\end{array}$ & sedikit & $\begin{array}{l}\text { rend } \\
\text { ah } \\
\text { seda }\end{array}$ & $\times 3$ \\
\hline$\times 4$ & SW03 & $\mathrm{ng}$ & $\begin{array}{l}\text { bulan } \\
\text { 12bul }\end{array}$ & sedang & $\mathrm{ng}$ & $\times 4$ \\
\hline$\times 5$ & SW02 & $\begin{array}{l}\text { Baik } \\
\text { Seda }\end{array}$ & $\begin{array}{l}\text { an } \\
7 \text { bula }\end{array}$ & $\begin{array}{l}\text { sedikit } \\
\text { sedann }\end{array}$ & $\begin{array}{l}\text { tinggi } \\
\text { rend }\end{array}$ & $\times 6$ \\
\hline$\times 6$ & SW05 & $\begin{array}{l}\text { ng } \\
\text { sanga }\end{array}$ & & $\mathrm{g}$ & $\mathrm{ah}$ & 人o \\
\hline$\times 7$ & SWOI & $\begin{array}{c}\text { t baik } \\
\text { sang }\end{array}$ & bulan & banyak & tinggi & $x /$ \\
\hline$x 8$ & SWOI & $\begin{array}{l}\text { at } \\
\text { baik } \\
\text { sang }\end{array}$ & $\begin{array}{l}12 \\
\text { bulan }\end{array}$ & $\begin{array}{l}\text { banya } \\
k\end{array}$ & $\begin{array}{l}\text { Ting } \\
\text { gi }\end{array}$ & $x 8$ \\
\hline$x 9$ & SWOI & $\begin{array}{l}\text { at } \\
\text { baik } \\
\text { sang }\end{array}$ & $\begin{array}{l}12 \\
\text { bulan }\end{array}$ & $\begin{array}{l}\text { banya } \\
k\end{array}$ & $\begin{array}{l}\text { tingg } \\
\mathrm{i}\end{array}$ & $\times 9$ \\
\hline$x \mid 0$ & SWOI & $\begin{array}{l}\text { at } \\
\text { baik }\end{array}$ & $\begin{array}{l}12 \\
\text { bulan } \\
12 \text { bula }\end{array}$ & $\begin{array}{l}\text { banya } \\
k\end{array}$ & $\begin{array}{l}\text { tingg } \\
\mathrm{i} \\
\text { tingg }\end{array}$ & $\begin{array}{l}\text { mina } \\
\mathrm{t} \\
\text { mina }\end{array}$ \\
\hline xII & SW02 & $\begin{array}{l}\text { Baik } \\
\text { Seda }\end{array}$ & $\begin{array}{l}n \\
9\end{array}$ & sedikit & $\begin{array}{l}\mathrm{i} \\
\text { seda }\end{array}$ & $\begin{array}{l}\mathrm{t} \\
\text { Tida }\end{array}$ \\
\hline$x \mid 2$ & SW03 & $\begin{array}{l}\text { ng } \\
\text { Seda }\end{array}$ & bulan & $\begin{array}{l}\text { sedang } \\
\text { sedan }\end{array}$ & $\begin{array}{l}\text { ng } \\
\text { rend }\end{array}$ & $\begin{array}{l}\mathrm{k} \\
\text { Tida }\end{array}$ \\
\hline$x \mid 3$ & SW05 & $\begin{array}{l}\text { ng } \\
\text { Sang }\end{array}$ & 7bulan & $\mathrm{ng}$ & ah & k \\
\hline$x \mid 4$ & SW05 & $\begin{array}{l}\text { at } \\
\text { baik }\end{array}$ & $\begin{array}{l}\text { 7bulan } \\
\text { I } 2 \text { bula }\end{array}$ & $\begin{array}{l}\text { sedan } \\
\text { ng }\end{array}$ & $\begin{array}{l}\text { rend } \\
\text { ah } \\
\text { tingg }\end{array}$ & $\begin{array}{l}\text { Tida } \\
k \\
\text { mina }\end{array}$ \\
\hline$x \mid 5$ & SW02 & Baik & $\begin{array}{l}n \\
\text { I } 2 \text { bula }\end{array}$ & sedikit & $\begin{array}{l}\mathrm{i} \\
\text { tingg }\end{array}$ & $\begin{array}{l}\mathrm{t} \\
\text { Tida }\end{array}$ \\
\hline$x 16$ & SW02 & $\begin{array}{l}\text { Baik } \\
\text { Sang }\end{array}$ & $\mathrm{n}$ & sedikit & i & k \\
\hline$x \mid 7$ & SW04 & $\begin{array}{l}\text { at } \\
\text { baik } \\
\text { Seda }\end{array}$ & $\begin{array}{l}7 \\
\text { bulan } \\
7\end{array}$ & sedikit & $\begin{array}{l}\text { rend } \\
\text { ah } \\
\text { rend }\end{array}$ & $\begin{array}{l}\text { mina } \\
\mathrm{t} \\
\text { mina }\end{array}$ \\
\hline$x 18$ & SW04 & $\begin{array}{l}\text { ng } \\
\text { Seda }\end{array}$ & bulan & $\begin{array}{l}\text { sedikit } \\
\text { sedan }\end{array}$ & $\begin{array}{l}\text { ah } \\
\text { rend }\end{array}$ & $\begin{array}{l}\mathrm{t} \\
\text { Tida }\end{array}$ \\
\hline$x 19$ & SW05 & $\begin{array}{l}\text { ng } \\
\text { sang }\end{array}$ & 7bulan & $\mathrm{ng}$ & ah & k \\
\hline$\times 20$ & SWOI & $\begin{array}{l}\text { at } \\
\text { baik } \\
\text { sang }\end{array}$ & $\begin{array}{l}12 \\
\text { bulan }\end{array}$ & $\begin{array}{l}\text { banya } \\
\text { k }\end{array}$ & $\begin{array}{l}\text { tingg } \\
\mathrm{i}\end{array}$ & $\begin{array}{l}\text { mina } \\
\mathrm{t}\end{array}$ \\
\hline$\times 21$ & SWOI & $\begin{array}{l}\text { at } \\
\text { baik } \\
\text { sang }\end{array}$ & $\begin{array}{l}12 \\
\text { bulan }\end{array}$ & $\begin{array}{l}\text { banya } \\
\text { k }\end{array}$ & $\begin{array}{l}\text { tingg } \\
\mathrm{i}\end{array}$ & $\begin{array}{l}\text { tida } \\
\mathrm{k}\end{array}$ \\
\hline$x 22$ & SWOI & $\begin{array}{l}\text { at } \\
\text { baik } \\
\text { Seda }\end{array}$ & $\begin{array}{l}12 \\
\text { bulan }\end{array}$ & $\begin{array}{l}\text { banya } \\
\mathrm{k} \\
\text { sedan }\end{array}$ & $\begin{array}{l}\text { tingg } \\
\mathrm{i} \\
\text { rend }\end{array}$ & $\begin{array}{l}\text { mina } \\
\mathrm{t} \\
\text { Tida }\end{array}$ \\
\hline$x 23$ & $\begin{array}{l}\text { SW05 } \\
\text { SW0 }\end{array}$ & $\begin{array}{l}\text { ng } \\
\text { Bai }\end{array}$ & $\begin{array}{l}\text { 7bulan } \\
\text { I 2bul }\end{array}$ & $\begin{array}{l}\text { ng } \\
\text { sediki }\end{array}$ & $\begin{array}{l}\text { ah } \\
\text { ting }\end{array}$ & k \\
\hline$\times 24$ & 2 & $\begin{array}{l}\text { k } \\
\text { san }\end{array}$ & an & $\mathbf{t}$ & gi & $?$ \\
\hline$\times 25$ & $\begin{array}{l}\text { SW0 } \\
\text { I }\end{array}$ & $\begin{array}{l}\text { gat } \\
\text { baik }\end{array}$ & $\begin{array}{l}12 \\
\text { bulan }\end{array}$ & $\begin{array}{l}\text { banya } \\
\text { k }\end{array}$ & $\begin{array}{l}\text { ting } \\
\text { gi }\end{array}$ & $?$ \\
\hline
\end{tabular}

Langkah awal yang dilakukan untuk proses perhitungan dengan algoritma naïve bayes adalah membuat data training dari laporan data penjualan sarang walet. Untuk Variable penentu yang digunakan dalam mengklasifikasikan minat konsumen terhadap sarang walet dapat diuraikan pada tabel berikut ini:

a. Sarang Walet

Sarang burung walet adalah variabel dari jenis sarang walet yang diklasifikasikan dalam beberapa kode jenis sarang burung walet

Tabel 3 Jenis Sarang Walet

\begin{tabular}{lll}
\hline No & Kode & \multicolumn{1}{c}{ Keterangan } \\
\hline I & SW01 & $\begin{array}{l}\text { Sarang Walet Putih Original } \\
\text { (mangkok) }\end{array}$ \\
2 & SW02 & Sarang Walet Merah \\
3 & SW03 & Sarang Walet Segitiga \\
4 & SW04 & Sarang Walet Patahan \\
5 & SW05 & Sarang Walet Strip \\
\hline
\end{tabular}

b. Masa Penyimpanan

Masa Penyimpanan merupakan variable yang digunakan untuk mengetahui berapa lama waktu bertahan sarang walet saat dilakukan penyimpanan, variable ini dikelompokkan menjadi tiga bagian yaitu 7 bulan, 9 bulan dan 12 bulan (I tahun).

Tabel 4 Masa Penyimpanan

\begin{tabular}{ll}
\hline Masa Penyimpanan & Keterangan \\
\hline 7 bulan & $\begin{array}{l}\text { Dapat disimpan selama } 7 \\
\text { bulan setelah pembelian } \\
\text { Dapat disimpan selama } 9 \\
\text { bulan }\end{array}$ \\
I 2 bulan & $\begin{array}{l}\text { Dapat disimpan selama I } \\
\text { tahun setelah pembelian }\end{array}$ \\
\hline
\end{tabular}

c. Harga

harga adalah salah satu variabel yang digunakan untuk mengetahui perbedaan harga antara jenis sarang burung walet, variabel jenis harga sarang burung walet ini dikelompokkan menjadi tiga yaitu rendah sedang dan tinggi (Harga dapat berubah setiap waktu) dapat dilihat pada tebl berikut ini

Tabel 4.4 Jenis Harga

\begin{tabular}{ccc}
\hline No & $\begin{array}{c}\text { Jenis } \\
\text { Harga }\end{array}$ & Keterangan \\
\hline I & Rendah & $\mathrm{I} .000 .000-5.000 .000$ \\
2 & Sedang & $6.000 .000-10.000 .000$ \\
3 & Tingggi & $13.000 .000-24.000 .000$ \\
\hline
\end{tabular}

Setelah menguraikan data training tahapan selanjutnya melakukan perhitungan dengan menggunakan algoritma naive bayes. Pada data training yang telah dibuat terdapat dua kasus baru sehingga algoritma yang dibaut sebagai berikut: 
1. Menghitung nilai probabilitas kasus baru dari setiap hipotesis dengan kelas label yang sudah ada "P(Xn|Ci)"

2. Menghitung nilai dari setiap kelas (label)

3. Menentukan kelas dari kasus

Berdasarkan data training dilakukan perhitungan untuk klasifikasi data kualitas sarang wallet, masa penyimpanan, ketersediaan dan harga dengan mengimplementasikan algoritma naive bayes, jika terdapat inputan data baru seperti yang ada pada data training maka ditentukan melalui langkah perhitungan berikut ini:

d. Menghitung nilai probabilitas " $\mathrm{P}(\mathrm{Xn} \mid \mathrm{Ci})$

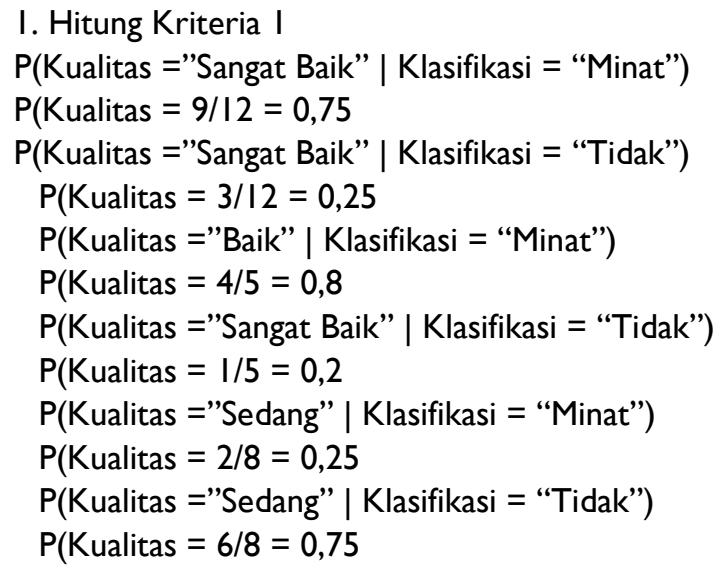

\section{Hitung Kriteria 2}

$\mathrm{P}($ Masa Penyimpanan =" 12 bulan" | Klasifikasi = "Minat")

$P($ Kualitas $=12 / 15=0.8$

$\mathrm{P}($ Masa Penyimpanan =” 12 bulan" | Klasifikasi = "Tidak")

$P($ Kualitas $=3 / 15=0,2$

$\mathrm{P}($ Masa Penyimpanan ="9 bulan" $\mid$ Klasifikasi = "Minat")

$\mathrm{P}($ Kualitas $=1 / 2=0.5$

$\mathrm{P}($ Masa Penyimpanan $=$ "9 bulan" $\mid$ Klasifikasi $=$ "Tidak") $\mathrm{P}($ Kualitas $=\mathrm{I} / 2=0,5$

$\mathrm{P}($ Masa Penyimpanan $=$ "7 bulan" $\mid$ Klasifikasi $=$ "Minat" $)$ $P($ Kualitas $=2 / 8=0.25$

$\mathrm{P}($ Masa Penyimpanan $=$ "7 bulan" $\mid$ Klasifikasi $=$ "Tidak" $)$ $\mathrm{P}($ Kualitas $=6 / 8=0,75$

\section{Hitung Kriteria 3}

$\mathrm{P}($ Ketersediaan ="Banyak" $\mid$ Klasifikasi = "Minat")

$P($ Kualitas $=8 / 10=0.8$

P(Ketersediaan ="Banyak" | Klasifikasi = "Tidak")

$\mathrm{P}($ Kualitas $=2 / 10=0,2$

$\mathrm{P}($ Ketersediaan $=$ "Sedang" $\mid$ Klasifikasi = "Minat")

$\mathrm{P}($ Kualitas $=\mathrm{I} / 7=0.14$

$\mathrm{P}($ Ketersediaan $=$ "Sedang” $\mid$ Klasifikasi = "Tidak")

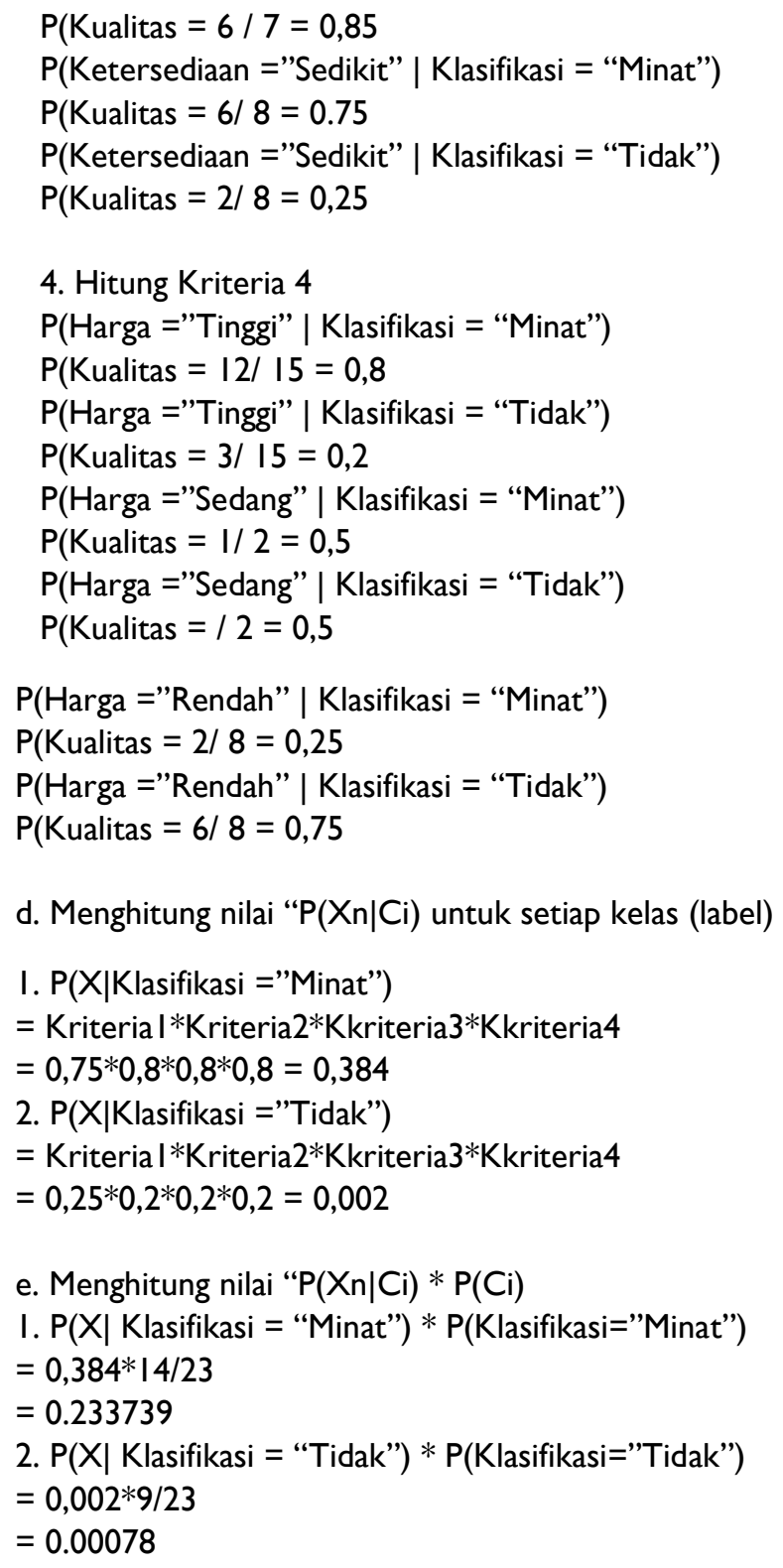

\section{e. Menentukan kelas dari kasus baru}

Dari hasil pembahsan dan perhitungan dengan algoritma naive bayes dengan melakukan perkalian nilai probabilitas atau nilai peluang dari kasus yang diambil dari data training dapat dilihat bahwa $P(X \mid$ Klasifikasi="Minat") mendapatkan hasil yang lebih besar dari $\mathrm{P}(\mathrm{X} \mid$ Klasifiakasi='Tidak") dengan nilai dari minat = 0.233739 dan nilai 0.00078 . Sehingga dapat diambil kesimpulan bahwa dua data kasus baru yang ada pada data training masuk dalam kategori klasifikasi "Minat"

\section{Implementasi Algoritma Naive Bayes Dengan RapidMiner}

Berdasarkan hasil penerapan algoritma naive bayes denga aplikasi rapidminer dengan melakukan olah data 


$$
\begin{aligned}
& \text { Sofyan,Siti Nur Asia,Mardewi. Implementasi Algoritma Naive Bayes Untuk Mengetahui Minat Beli } 2021 \\
& \text { Konsumen Terhadap Sarang Burung Walet }
\end{aligned}
$$

training dengan dua kasus baru dapat dilihat pada hasil bahwa data kasus baru yang ada pada data training termasuk dalam kategori klasifikasi “Minat" dengan hasil prediksi minat dengan angka confidentce minat sebesar 0.983 dengan konsumen 24 dan 0.990 untuk konsumen 25 dengan perbandingan hasil confidence tidak sebesar 0,017 dan 0.010

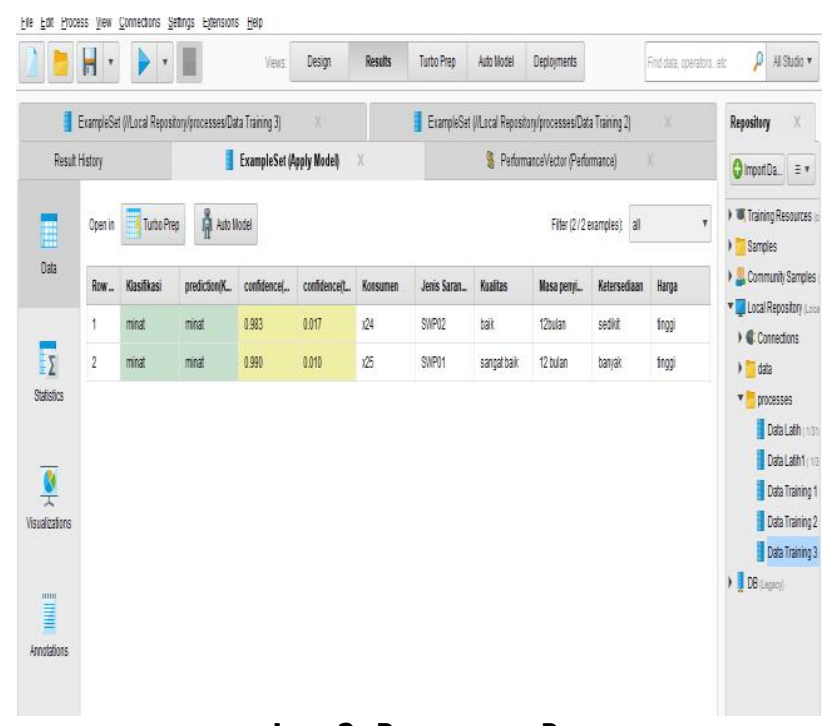

gambar 2 Pemesanan Barang

\section{Simpulan Dan Saran}

A. Kesimpulan

Trisetiyo, Mohamat Dodi, and Jati Sasongko Wibowo. 2019. "Klasifikasi Surat Menggunakan Metode Naïve Bayes Pada Sistem Informasi Manajemen Surat." 978-79.

Trisetiyo, M. D., \& Wibowo, J. S. (2019). Klasifikasi Surat Menggunakan Metode Naïe Bayes Pada Sistem Informasi Manajemen Surat. 978-979. Aban, N., \& Tanusi, G. (2020). Faktor - Faktor Yang Mempengaruhi Minat Berwirausaha Mahasiswa Program Studi Manajemen Fakultas Ekonomi Universitas Flores. Analisis, 19(I), 76-84. https://doi.org/l0.37478/analisis.v19il.325

Alinda, N. (20/3). Analisis Faktor-Faktor Yang Mempengaruhi Ekspor Karet Di Indonesia. Jurnal Ekonomi Pembangunan, II(I), 93. https://doi.org/10.22219/jep.vI Iil.3733

A. P. Wijaya. 2016. "Klasifikasi Dokumen dengan Naive Bayes Classifier (NBC) untuk Mengetahui Konten E- Goverment,"Journal of Appliedlntelligent System, Vol. I, No. I, pp. 48-55,

Arifin, M. S., Rahayuningsih, M., \& Ngabekti, S. (2012). Distribusi Walet (Collocalia sp) di Kabupaten Grobogan. Shengming Kexue, I(I).
Dari hasil perancangan, analisa serta implementasi yang telah dlakukan pada Implementasi Algoritma Naive Bayes untuk Mengetahui Minat Beli Konsumen Terhadap Sarang burung Walet, maka dapat disimpulkan bahwa Algoritma naive bayes dapat diimplementasikan dalam memprediksi peluang di masa mendatang berdasarkan analisis yang telah dilakukan dengan sampel data training dan dari hasil uji coba dengan sampel data training sebanyak 25 sampel yang terdiri dari 23 sampel lama dan dua sampel data kasus baru yaitu P(X|Klasifikasi="Minat") mendapatkan hasil yang lebih besar dari $\mathrm{P}($ X|Klasifiakasi='Tidak") dengan nilai dari minat = 0.233739 dan nilai 0.00078. dan berdasarkan hasil implemntasi dengan Rapidminer termasuk dalam kategori klasifikasi “Minat" dengan hasil prediksi minat dengan angka confidentce minat sebesar 0.983 dengan konsumen 24 dan 0.990 untuk konsumen 25 dengan perbandingan hasil confidence tidak sebesar 0,017 dan 0.010 sehinggan dapat disimpulkan kualitas sarang burung wallet sangat dibutuhkan konsumen.

\section{B. Saran}

Adapun saran kedepannya Untuk pengembangan peneliti selanjutnya sangat diharapkan menambahkan kriteria sebagai parameter penilian tambahan dan Menambah jumlah data taraining serta dapat menambah algoritma prediksi lainnya sebagai bahan perbandingan

\section{Pustaka Acuan}

Ayuti, T., Garnida, D., Asmara, Y., Fakultas, A., Unpad Tahun, P., Fakultas, S. P., \& Unpad, P. (20I6). Identifikasi Habitat dan Produksi Sarang Burung Walet (Collocalia fuciphaga)...... Turaina Ayuti IDENTIFIKASI HABITAT DAN PRODUKSI SARANG BURUNG WALET (Collocalia fuciphaga) DI KABUPATEN LAMPUNG TIMUR SWIFTLET (Collocalia fuciphaga) NEST PRODUCTION AND HABITAT IDENTIFICATION AT EAST LAMPUNG DISTRICT.

Basofi et al. (2020). Jurnal Environmental Science. Jurnal Environmental Science, I(April), I-7.

Hermawan, C., \& Seabtian, D. T. (20/4). Sistem Pendukung Keputusan Penentuan Lokasi Pembangunan Sarang Walet Menggunakan Metode Analytic Hierarchy Process. 20(1), 12-16.

Nuroini, F., \& Wijayanti, N. (2017). UJI EFEK ANTIINFLAMASI EKSTRAK AKUOSA SARANG BURUNG WALET (Collocalia fuciphaga Thunberg) TERHADAP GAMBARAN HISTOLOGIS TELAPAK KAKI MENCIT (Mus musculus Linneaus). Jurnal Labora Medika, I(I), 2I-26.

Nofriansyah, D., Erwansyah, K., \& Ramadhan, M. (2016). Penerapan Data Mining dengan Algoritma Naive Bayes Clasifier untuk Mengetahui Minat Beli Pelanggan terhadap Kartu Internet XL ( Studi 
Kasus di CV. Sumber Utama Telekomunikasi). Jurnal Saintikom, 15(2), 8I-92.

Pramono, R. (2016). Minat Beli. Diponegoro Business Review, 6-19.

Putro, H. F., Vulandari, R. T., \& Saptomo, W. L. Y. (2020). Penerapan Metode Naive Bayes Untuk Klasifikasi Pelanggan. Jurnal Teknologi Informasi Dan Komunikasi (TIKomSiN), https://doi.org//0.30646/tikomsin.v8i2.500

Rahmawati, E., \& Rusidah, S. (2019). Analisis Lingkungan Bisnis dan Harga Jual terhadap Minat Pengusaha Budidaya Sarang Burung Walet di Kelurahan Beriwit Kecamatan Murung Kabupaten Murung Raya Kalimantan Tengah. 8(2).

Syahrantau, G., \& M.Yandrizal, M. Y. (2018). ANALISIS USAHA SARANG BURUNG WALET DIKELURAHAN TEMBILAHAN KOTA (Studi Kasus Usaha Sarang Burung Walet Pak Sutrisno). Jurnal Agribisnis, 7(I), 74-85. https://doi.org// 0.32520/agribisnis.v7il.165 